УДК 338: 669

DOI: $10.15673 /$ fie.v12i4.1907

\author{
Бігунов-Новіков Л.Ю. \\ аспірант \\ кафедра бізнес-економіки та підприємництва \\ Київський національний економічний університет ім. Вадима Гетьмана \\ проспект Перемоги, 54, м. Київ, Україна, 03057 \\ E-mail: begunov.leonid@gmail.com \\ ORCID ID: 0000-0002-8020-4710
}

\title{
КОНТРАКТНІ ФОРМИ УПРАВЛІННЯ СІТЬОВИМИ БІЗНЕС-СТРУКТУРАМИ
}

Парадигма неокласичної економіки базується переважно на досліджені виробництва та споживання. Однак, великий науковий інтерес також викликає організація обміну, дослідження якого неможливе без аналізу контрактних угод передачі прав власності на активи. В статті розглянуті форми контрактного управління сітьовими бізнес-структурами, які використовуються учасниками обміну в умовах невизначеності як альтернативний механізм адаптації до зовнішнього середовища через ринок (класичну контрактацію) та об'єднане управління (вертикальну і горизонтальну інтеграцію). Вперше визначені види формальних реляційних сітьових контрактів та механізми мінімізації невизначеності, якими вони регламентують обмін між учасниками сітьових бізнес-структур. Описані основні умови невизначеності, які дозволяють управлінцям, суб'єктам прийняття рішень робити висновки щодо доцільності фрормування сітьових бізнес-структур як найбільш ефективних та найменш трансакційно витратних структур управління в умовах невизначеності.

Ключові слова: Сітьові бізнес-структури, стратегічні альянси, консорціуми, концерни, форварди, опціони, венчурне фрінансування, асоціації підприємств, реляційний контракт.

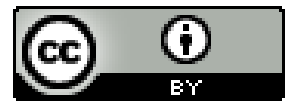

This work is licensed under a Creative Commons Attribution 4.0 International License http://creativecommons.org/licenses/by/4.0/
Постановка проблеми та їі зв'язок 3 важливими науковими та практичними завданнями. Парадигма неокласичної економіки базується переважно на досліджені виробництва та споживання. Однак, великий науковий інтерес також викликає організація обміну, дослідження якого неможливе без аналізу контрактних угод передачі прав власності на активи. Поглиблене вивчення обміну зі сторони економістів через «провали ринки» 3 другої половини $\mathrm{XX}$ століття призвело до зміщення акцентів аналізу контрактів 3 чисто правових аспектів договірного процесу до більш широкої оцінки суспільноекономічних цілей, які такі угоди переслідують [11], зокрема щодо забезпечення найменш трансакційно витратного механізму управління трансакціями, оскільки задачею будь-якої системи контрактного права $є$ полегшення процесу обміну [7]. На сьогодні достатньо вивченою є класична та неокласична контрактація, яка характерна переважно для дискретного і раціонального ринкового обміну, а також взаємовідносницька контрактація, пов'язана 3 системою управління персоналом, трудовими та колективними договорами на підприємстві. В той же час, природа і механізми функціонування довгострокової автономної взаємовідносницької контрактації економічний суб'єктів, характерної для сітьових бізнес-структур, є недослідженими, хоча бізнесова практика демонструє безліч прикладів сітьової взаємодії, починаючи від простих торгівельних агентських договорів до складноструктурованих міжнародних стратегічних альянсів, яких кожного року утворюється близько 4000 одиниць в усьому світі, і це тільки серед великих підприємств [13]. Як зазначив П. Друкер на одній із публічних лекцій, сучасний бізнес росте за рахунок самих різноманітних альянсів, спільних підприємств і партнерства зі споживачами, але, нажаль, це розуміють лише одиниці [13].

Аналіз останніх досліджень та публікацій. Економічна теорія контрактів - відносно нова дисципліна, яка вперше була досконало описана Яном Макнейлом $[6,7,8,9]$, а згодом адаптована для цілей порівняльного інституційного аналізу Уільямсоном $[10,11]$ і Голдбергом [1]. Змістовні роботи по дослідженню взаємовідносницької контрактації, крім Макнейла, можна знайти у Маколея [5], який першим навів результати емпіричних досліджень щодо не юридичного (судового), а приватного механізму вирішення спорів, що характерний для взаємовідносницької контрактації, а також у Алчіана зі співавторами [3], де аналізується важливість проблеми присвоєння квазірент на ex post стадії реалізації контракту. 3 емпіричними дослідженнями теоретичних викладок Уільямсона можна ознайомитися у роботі Йоскова [2]. Важливою для цілей аналізу взаємовідносницької контрактації є робота Кронмана [4], де описані фундаментальні проблеми виконання контракту в умовах 
відсутності правового централізму (держави).

Формулювання цілей дослідження. Ціллю даної статті $€$ висвітлення результатів дослідження природи виникнення і функціонування контрактних форм управління сітьовими бізнес-структурами, які автономно функціонують на базі взаємовідносницької контрактації, альтернативної до ринку та фірми (iєрархіï). Зокрема, практичний інтерес представляють формальні (юридичні) форми контрактів, які можуть бути застосовані суб'єктами прийняття рішень для ведення господарської діяльності в умовах невизначеності як спосіб іiі мінімізації.

Методи дослідження. У ході дослідження використано загальнонаукові та спеціальні методи наукового пізнання, що зумовлено поставленою метою. Для отримання наукових результатів було використано такі методи: бібліографічного аналізу - для впорядкування наукових позицій щодо аналітичної інтерпретації контрактних форм управління сітьовими бізнес-структурами; наукового узагальнення - при систематизації методичних підходів до інтерпретації контрактних форм управління сітьовими бізнесструктурами; метод причинно-наслідкових зв'язків при впорядкуванні та визначенні управлінських аспектів контрактними формами у діяльності сітьових бізнес-структур.
Інформаційною базою дослідження стали монографії, збірники наукових праць, ресурси мережі Інтернет, а також результати власних досліджень авторів.

Виклад основних результатів та їх обгрунтування. Відповідність юридичних контрактів організаційним формам управління описав Уільямсон у своїй класичній роботі [11], спираючись на роботи Макнейла [6,7]. За Уільямсоном, головним завданням фірми є не максимізація прибутку, а мінімізація трансакційних витрат, що досягається за рахунок створення правильних контрактних стимулів та стримувань опортуністичної поведінки у відносинах між сторонами. Прибуток в такій інституційній трактовці $€$ премією за ризики, пов'язанні 3 трансакційними витратами, які виникають внаслідок функціонування таких контрактних механізмів [14]. Уільямсон стверджує, що про організацію і структуру управління можна багато дізнатися, аналізуючи частоту трансакцій та специфічність інвестицій, які здійснюють сторони контракту. В залежності від конкретної конфігурації «частота трансакцій - специфічність інвестицій», яка існує на даний момент, можна виділити чотири різних типи структур управління, що показані на рис. 1.

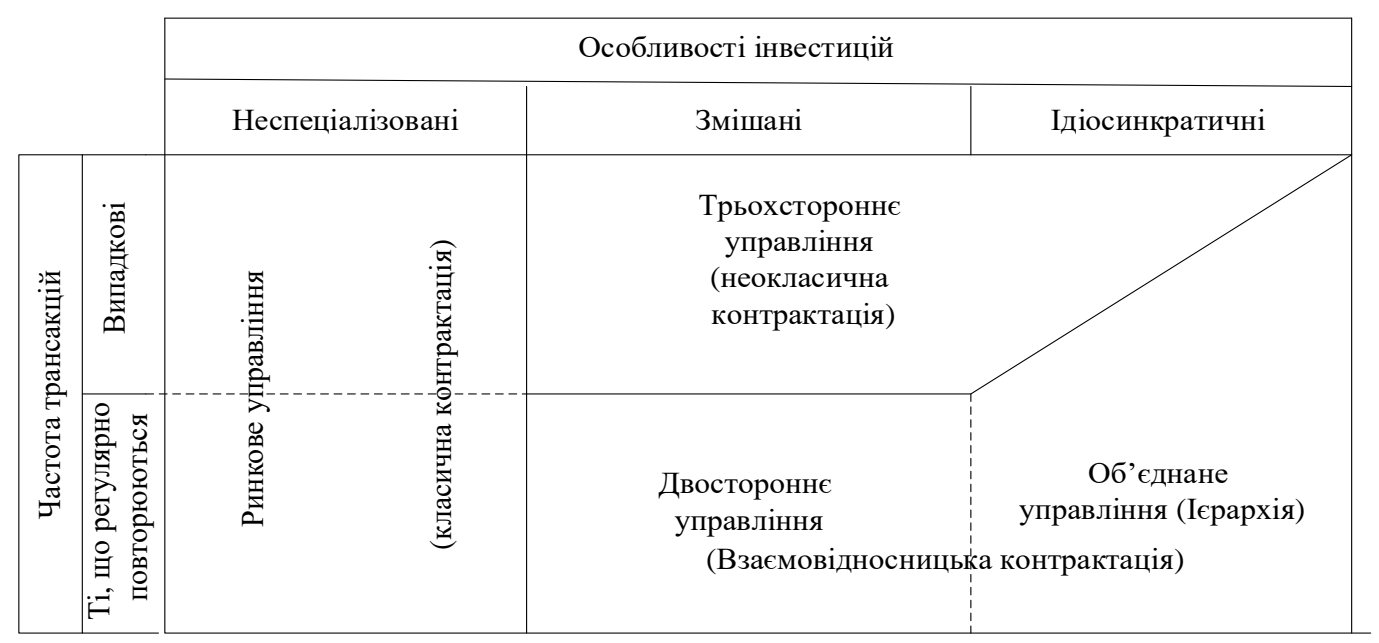

Рис. 1. Форми ефективного управління трансакціями [11]

Механізм ринкового управління контрактами являється основною структурою управління неспеціалізованими трансакціями, як випадковими, так і тими, що регулярно повторюються. Ринок являється особливо дієвим тоді, коли пропонується використовувати ті трансакції, які регулярно повторюються, оскільки в цьому випадку обидві сторони повинні проаналізувати тільки свій минулий досвід виконання трансакцій для того щоб вирішити, продовжувати торгові відносини з стороною або, з невеликими витратами, замінити партнера. У випадку, коли виконується випадкова, неспеціалізована трансакція, сторони не мають можливості покладатися на свій досвід, але в таких випадках можна звернутися до порівняльної оцінки характеристики послуг, або до досвіду інших покупців даного товару в силу їх стандартності (не специфічності). Інструментами захисту кожної сторони від опортуністичної поведінки партнерів по угоді в основному являються ринкові альтернативи або судові вирішення спорів (класична контрактація). Так як на ринку спостерігається автономність (незалежність) відносин учасників, зміни, що відбуваються в зовнішньому середовищі (зміна попиту та пропозиції, технологій, інституціонального середовища тощо), викликають цінову адаптацію, тобто учасники ринкових відносин адаптуються до змін, реагуючи на зміну ціни, що являється ефективним барометром $\mathrm{i}$ стимулює загальну рівновагу (визначеність) на ринках. 
Об'єднане управління виникає (стає ефективним) при досягненні певного достатньо високого рівня специфічності активів (активи, інвестиції в які сторони роблять контрено для виконання спільної угоди і які важко потім перепродати на ринку через їх специфічність до даної трансакції). По мірі зростання специфічності активів зростають стимули до опортуністичної поведінки учасників таких трансакцій та послаблюються стимули до ринкової торгівлі. Окрім того, специфічність активів викриває обмежену раціональність учасників, оскільки в силу їх нестандартності актори не можуть передбачити в контрактах всі можливі випадки регулювання взаємовідносин. Таким чином, виникає феномен вертикальної інтеграції (об’єднаного управління) як засіб мінімізації трансакційних витрат. Вертикальна інтеграція, використовуючи адміністративно-командні методи, систему управління персоналом (за рахунок взаємовідносницької контрактації через трудові і колективні угоди), може легше адаптуватися до змін, оскільки не виникає необхідності формально заключати нові або перезаключати контракти між акторами, виникає адміністративна адаптація. Людські та фізичні активи фірми все більше спеціалізуються на виконанні єдиної задачі, що означає погодження всіх цілей елементів системи вертикальної інтеграції навколо єдиної цілі.

Неокласична (або тристороння) контрактація відрізняється від класичної ринкової контрактації та об'єднаного управління ієрархій і зводиться до умови наявності в контракті третьої сторони (наприклад, третейського судді). Вона виникає тоді, коли інвестиції є специфічними, але разовими. Специфічність унеможливлює застосування ринкової контрактації і застосування класичної судової практики через відсутність прецедентів вирішення спорів. 3 іншою сторони, разовість угоди ставить питання довіри між сторонами, тому залучення третейського судді (третьої сторони), як гаранта врегулювання конфліктів, $€$ доцільним, оскільки передбачається, що третя сторона знається на специфіці індустрії, де відбувається угода, та користується довірою серед учасників такої угоди.

Змішана форма управління (двосторонне управління, сітьові бізнес-структури) - об'єкт аналізу даної роботи - не є достатньо вивченим в рамках теорії трансакційних витрат і економічної теорії контрактів. Уільямсон правильно відносить таку форму управління до взаємовідносницької контрактації, але концентрація уваги на частоті і специфічності трансакцій не дає вченому інструментарію для пояснення природи формування сітьових бізнес-структур. Зокрема, він сам визнає це: «...За умови частих специфічних трансакцій, які, зазвичай, спричиняють утворення вертикальної інтеграції, тобто утворення ієрархії (фірми), можуть виникати двосторонні структури управління трансакціями, які зберігають автономність учасників угоди...однак функціонування таких структур на даний час найменш досліджене» [11].

Ми стверджуємо, що природа формування сітьових бізнес-структур може бути досліджена при поглибленому аналізі такого атрибуту трансакцій як невизначеність, а не частота трансакцій чи специфічність активів. Ми можемо говорити про невизначеність, якщо існує хоча б одна з наступних трьох умов:

1. Велика частка нематеріальних активів, які виступають предметами обміну (знання, технології, інформація, інтелектуальний капітал тощо), які важко ідентифікувати, захистити та оцінити їх вклад до доданої вартості, в тому числі через загострення проблеми оцінки корисних якостей таких активів і асиметрії інформації між власником і покупцем на нематеріальні активи;

2. Ринкова невизначеність: непрогнозованість попиту на ринку, непрогнозованість ціноутворення та собівартості, турбулентність ринків, сезонність, стрімка зміна традиційних ринків за рахунок нових технологій, відсутність досвіду роботи на тому чи іншому ринку тощо;

3. Невизначеність інституційного середовища, пов'язана з роботою державних інститутів і законодавчим регулюванням галузей, що породжує додаткові трансакційні витрати по захисту прав власності, недосконалості роботи судової системи, контролюючих органів, змін законодавства на користь конкурентів тощо.

Наявність хоча б однієї з умов невизначеності поглиблює труднощі в оцінці активів при обміні, що суттєво збільшує трансакційні витрати, які опосередковують обмін. Проблема оцінки виникає в силу складності визначення усіх властивостей активів, що $\epsilon$ предметом обміну на передконтрактній стадії договірного процесу, а також через постконтратні витрати, пов'язаних з асиметрією інформації і забезпеченням умов виконання трансакцій $[11,14]$. Зокрема, для оцінки, контролю, захисту та примусу виконання угоди учасники обміну витрачають колосальні зусилля, час і кошти на юридичні гарантії, залоги, поручительства, торгові марки, ресурси по сортуванню та класифікації для полегшення оцінки, хронометражу робочого часу, найму третіх сторін (консультанти, оцінщики і т.д.), на судові і третейські спори, і взагалі всю систему юридичного забезпечення - всі ці дії виражають всепроникаючий характер необхідності оцінки, контролю і відповідних трансакційних витрат, які виникають для здійснення реалізації процесу обміну.

Тому ми ж стверджуємо, що в умовах високого рівня невизначеності виникають альтернативні до ринку та ієрархії сітьові бізнес-структури, учасники яких відмовляються від здійснення витрат на оцінку кожного акту обміну задля досягнення спільних майбутніх цілей, егоїстичний інтерес змінюється спільними інтересами. Така ситуація стає можливою, тому що в умовах низького рівня можливості оцінки активів, за високого рівня невизначеності, витрати опортунізму не збільшуються, як зазначає Уільямсон [11], а зменшуються, оскільки вигоди від кооперації перевищують вигоди опортуністичної поведінки, що $\epsilon$ джерелом трансакційних витрат. Між сторонами обміну виникають реципрокні взаємовідносини, які забезпечують досягнення конкурентних переваг за рахунок кооперації, а не конкуренції. Трансакції 
набувають персоніфікованого характеру і відповідно до теорії ігор, в малих групах (сітях), кооперація $є$ можливою і вигідною [14].

Концентрація на спільних цілях дозволяє застосувати принцип спільності інтересів, який на практиці виражається в основному в ex ante домовленостях щодо принципів розподілу майбутніх ризиків, доходів і витрат учасниками угоди, що є достатньою умовою забезпечення достовірних зобов'язань. Зокрема, Макнейл [6] зазначає, що на одній із фаз розвитку своїх відносин, учасники взаємовідносницького контракту або явно, або неявно домовляються щодо процедури («конституції»), яка використовується для розв'язання будь-яких проблем, які можуть виникнути в майбутньому. Іншими словами, сторони приймають ту основу, на базі якої вони будуть погоджувати нові угоди в явній чи неявній формі, якщо того потребуватимуть обставини.

В Таблиці 1 представлені формальні (явні) сітьові взаємовідносницькі договори, які можуть використовуватися економічними суб'єктами як альтернативні до класичних ринкових договорів або до об'єднаного управління процедур для адаптації в умовах високого рівня невизначеності.

Таблиця 1

Види сітьових формальних договорів в залежності від характеру невизначеності*

\begin{tabular}{|c|c|c|c|}
\hline № & $\begin{array}{c}\text { Сітьові формальні } \\
\text { договори } \\
\end{array}$ & Умови невизначеності & $\begin{array}{c}\text { Iнструменти зменшення } \\
\text { невизначеності } \\
\end{array}$ \\
\hline 1. & $\begin{array}{l}\text { Агентський договір } \\
\text { щодо збуту продукції } \\
\text { чи послуг }\end{array}$ & $\begin{array}{l}\text { Невизначеність попиту, відсутність дос- } \\
\text { віду роботи на певному ринку (особливо } \\
\text { зарубіжному), складний продукт чи пос- } \\
\text { луга, яка потребує висококваліфікованих } \\
\text { та досвідчених спеціалістів з продажу, що } \\
\text { мають відповідні зв'язки та розуміння } \\
\text { ринку, особливо поширена практика в } \\
\text { сегменті В2В. }\end{array}$ & $\begin{array}{l}\text { Оплата за послуги агента здійсню- } \\
\text { ється тільки за фактично продану } \\
\text { продукцію чи послуги. }\end{array}$ \\
\hline 2. & $\begin{array}{l}\text { Дольові контракти } \\
\text { майбутніх продажів }\end{array}$ & $\begin{array}{l}\text { Невизначеність попиту на продукцію. } \\
\text { Часто застосовується в креативних індус- } \\
\text { тріях: видавничій діяльності, індустрії } \\
\text { моди, кіно-виробництві тощо. }\end{array}$ & $\begin{array}{l}\text { Гонорар автора (дизайнера, інже- } \\
\text { нера, сценариста і т.д.) залежить } \\
\text { від фактично проданої продукції }\end{array}$ \\
\hline 3. & $\begin{array}{l}\text { Засновницький договір, } \\
\text { акціонерна угода } \\
\text { (Shareholders' } \\
\text { agreement) }\end{array}$ & $\begin{array}{l}\text { Відсутність досвіду роботи на ринку, ро- } \\
\text { звиток нових ринків, відсутність одноо- } \\
\text { собового володіння необхідними немате- } \\
\text { ріальними активами, знаннями, фінансо- } \\
\text { вими ресурсами. }\end{array}$ & $\begin{array}{l}\text { Прописується розподіл майбутніх } \\
\text { ризиків, долі участі в розподілу } \\
\text { прибутків і витрат, принципи «ви- } \\
\text { ходу» } 3 \text { бізнесу. }\end{array}$ \\
\hline 4. & $\begin{array}{l}\text { Ексклюзивні договори } \\
\text { дистрибуції продукції } \\
\text { та послуг }\end{array}$ & $\begin{array}{l}\text { Невизначеність попиту, відсутність дос- } \\
\text { віду роботи на певному ринку (особливо } \\
\text { зарубіжному). }\end{array}$ & $\begin{array}{l}\text { Монополія на продаж продукції чи } \\
\text { послуг на певній території }\end{array}$ \\
\hline 5. & $\begin{array}{l}\text { Довгострокові угоди } \\
\text { про постачання проду- } \\
\text { кції та послуг }\end{array}$ & $\begin{array}{l}\text { Непрогнозованість попиту кінцевого } \\
\text { продукту, цінова/собівартісна невизначе- } \\
\text { ність на ринку, сезонність на ринку, що } \\
\text { впливає на усіх контрагентів по усьому } \\
\text { ланцюгу створення вартості продукції і } \\
\text { змушує учасників такої сіті розглядати } \\
\text { обмін та виробництво в контексті спіль- } \\
\text { них інтересів і коопераційної адаптації, а } \\
\text { не виключно власних інтересів максимі- } \\
\text { зації прибутку в конкретний момент часу. }\end{array}$ & $\begin{array}{l}\text { Для врегулювання відносин тран- } \\
\text { сакції координуються не цінами } \\
\text { спот-ринку, а на основі гнучких } \\
\text { домовленостей про постачання } \\
\text { продуктів, розрахунку витрат, фік- } \\
\text { сованих цін (форвардних цін) і } \\
\text { розподілі майбутніх прибутків } \\
\text { тощо. }\end{array}$ \\
\hline 6. & Франчайзинг & $\begin{array}{l}\text { Відсутність досвіду роботи на ринку од- } \\
\text { нієї із сторін угоди. }\end{array}$ & $\begin{array}{l}\text { Франчайзер передає франчайзі } \\
\text { досвід, процедури ведення бізнесу, } \\
\text { право користуватися торговою } \\
\text { маркою тощо взамін на одноразо- } \\
\text { вий платіж та щомісячні платежі, } \\
\text { які залежать від обсягу реалізації. }\end{array}$ \\
\hline 7. & Форвардний контракт & Непрогнозованість цін на активи & $\begin{array}{l}\text { Договір, що укладається сторона- } \\
\text { ми про здійснення на поставки у } \\
\text { майбутньому на умовах, визначе- } \\
\text { них на момент його укладання. } \\
\text { Сторони несуть ризик зміни ціни } \\
\text { на базовий актив (як в сторону } \\
\text { збільшення, так і в сторону змен- } \\
\text { шення). }\end{array}$ \\
\hline
\end{tabular}


Продовження табл. 1

\begin{tabular}{|c|c|c|c|}
\hline № & $\begin{array}{c}\text { Сітьові формальні } \\
\text { договори }\end{array}$ & Умови невизначеності & $\begin{array}{c}\text { Інструменти зменшення } \\
\text { невизначеності }\end{array}$ \\
\hline 8. & Опціони & $\begin{array}{l}\text { Невизначеність кон’юнктури ринку у } \\
\text { майбутньому }\end{array}$ & $\begin{array}{l}\text { Опціон засвідчує право однієї із } \\
\text { сторін придбати або право прода- } \\
\text { ти у майбутньому базовий актив } \\
\text { на умовах визначених на час укла- } \\
\text { дення такого опціону. }\end{array}$ \\
\hline 9. & $\begin{array}{l}\text { Об’єднання підпри- } \\
\text { ємств (асоціації, консо- } \\
\text { рціуми, концерни) }\end{array}$ & $\begin{array}{l}\text { Наявність унікальних компетенцій, знань, } \\
\text { інформації, навиків інших нематеріаль- } \\
\text { них активів у окремих учасників транса- } \\
\text { кцій, які неможливо купити на ринку чи } \\
\text { відтворити всередині однієї компанії; } \\
\text { непрогнозованість отримання результатів } \\
\text { створення нового продукту, пов'язаних } 3 \\
\text { НІОКР; складністю реалізації складного } \\
\text { проекту одним учасником, який не може } \\
\text { взяти на себе усі ризики. }\end{array}$ & $\begin{array}{l}\text { Створення окремої юридичної } \\
\text { особи, яка забезпечує координацію } \\
\text { спільної виробничої, наукової та } \\
\text { іншої діяльності і участь в розпо- } \\
\text { ділі ризиків і прибутків учасника- } \\
\text { ми; збільшує бар'єри для появи } \\
\text { конкурентів в галузі; збільшує } \\
\text { довіру до об'єднання підприємств } \\
\text { з боку контрагентів у порівнянні } \\
\text { окремими п् підприємствами- } \\
\text { учасниками об'єднань. }\end{array}$ \\
\hline 10. & Стратегічні альянси & $\begin{array}{l}\text { Наявність унікальних компетенцій, знань, } \\
\text { інформації, навиків інших нематеріаль- } \\
\text { них активів у окремих учасників транса- } \\
\text { кцій, які неможливо купити на ринку чи } \\
\text { відтворити всередині однієї компанії; } \\
\text { відсутність досвіду роботи на ринку (за- } \\
\text { звичай міжнародному), створення нових } \\
\text { ринків та продуктів, непрогнозованість } \\
\text { отримання результатів створення нового } \\
\text { продукту, пов’язаних з НІОКР. }\end{array}$ & $\begin{array}{l}\text { Укладання функціональних угод } \\
\text { (договорів про спільну діяльність) } \\
\text { між учасниками (поширене зокре- } \\
\text { ма міжнародне співробітництво), } \\
\text { наприклад щодо спільних НІОКР, } \\
\text { спільних маркетингових дослі- } \\
\text { джень, розподілу фінансових ри- } \\
\text { зиків проектів тощо. При укладан- } \\
\text { ні функціональних угод нове підп- } \\
\text { риємство не створюється. Як пра- } \\
\text { вило, підприємства передають } \\
\text { ресурси для ведення спільної дія- } \\
\text { льності, але розподілу власності } \\
\text { при цьому не відбувається. }\end{array}$ \\
\hline 11. & $\begin{array}{l}\text { Асоційовані підприєм- } \\
\text { ства }\end{array}$ & $\begin{array}{l}\text { Наявність унікальних компетенцій, знань, } \\
\text { інформації, навиків інших нематеріаль- } \\
\text { них активів у окремих учасників транса- } \\
\text { кцій, які необхідні для ефективного } \\
\text { управління господарською діяльністю - } \\
\text { ризики неефективного управління, що } \\
\text { потребують додаткового захисту інвести- } \\
\text { цій через участь в управлінні. }\end{array}$ & $\begin{array}{l}\text { Перехресний викуп акцій/викуп } \\
\text { неконтрольного пакету акцій. } \\
\text { Компанія, в якій інша компанія } \\
\text { або група володіє значним, але не } \\
\text { контрольним пакетом акцій (най- } \\
\text { частіше } 20 \% \text { або більше голосую- } \\
\text { чих акцій, але менше 50\%). У та- } \\
\text { кому випадку компанія-інвестор } \\
\text { може мати значний вплив на рі- } \\
\text { шення по торговельній та фінан- } \\
\text { совій політиці асоційованої ком- } \\
\text { панії, хоча остання залишаєтья } \\
\text { незалежною, зі своїм власним ке- } \\
\text { руванням і власної річний звітніс- } \\
\text { тю, не перетворюючись на дочір- } \\
\text { ню фірму холдингової компанії. }\end{array}$ \\
\hline 12. & $\begin{array}{l}\text { Спільні підприємства у } \\
\text { зовнішньоекономічній } \\
\text { діяльності }\end{array}$ & $\begin{array}{l}\text { Ризики виходу на нові ринки збуту як } \\
\text { економічного, інституційного характеру, } \\
\text { так і соціального характеру (наприклад, } \\
\text { неприйняття міжнародний інвестицій } \\
\text { певний з певний країн в локальному на- } \\
\text { ціональному середовищі) }\end{array}$ & $\begin{array}{l}\text { Розподіл ризиків, участь у розпо- } \\
\text { ділі майбутніх прибутків, колекти- } \\
\text { вна відповідальність за взяті зо- } \\
\text { бов'язання. }\end{array}$ \\
\hline 13. & Венчурне інвестування & $\begin{array}{l}\text { Ризики розробки нової, зазвичай наукоє- } \\
\text { мної продукції, наявності попиту на неї; } \\
\text { ризик розвитку нового ринку продукції } \\
\text { чи послуг. }\end{array}$ & $\begin{array}{l}\text { Поетапне (стадійне) фінансування } \\
\text { проектів, яке відбувається по мірі } \\
\text { розробки продукції, появи клієн- } \\
\text { тури, генерації грошових потоків: } \\
\text { чим більш «зрілим» стає венчур- } \\
\text { ний проект - тим більше він може }\end{array}$ \\
\hline
\end{tabular}


Продовження табл. 1

\begin{tabular}{|c|c|c|c|}
\hline № & $\begin{array}{c}\text { Сітьові формальні } \\
\text { договори }\end{array}$ & Умови невизначеності & $\begin{array}{c}\text { Інструменти зменшення } \\
\text { невизначеності }\end{array}$ \\
\hline & & & $\begin{array}{l}\text { претендувати на фінансування } 3 \\
\text { боку інвесторів для цілей масшта- } \\
\text { бування. Це забезпечує страху- } \\
\text { вання ризиків інвесторів. Виділя- } \\
\text { ють як правило seed-стадію фінан- } \\
\text { сування, серію А, серію В. }\end{array}$ \\
\hline 14. & $\begin{array}{l}\text { Інститути спільного } \\
\text { інвестування (ICI) }\end{array}$ & $\begin{array}{l}\text { Фінансові ризики, ризики непрофесійно- } \\
\text { го керівництва, відсутність досвіду робо- } \\
\text { ти на ринках. }\end{array}$ & $\begin{array}{l}\text { Для управління інвестиціями уча- } \\
\text { сників ICI створюється компанія } \\
\text { по управлінню активами, яка } \\
\text { складається } 3 \text { професійного мене- } \\
\text { джменту, який володіє необхідним } \\
\text { досвідом і знаннями, експертизою } \\
\text { ринку для здійснення ефективних } \\
\text { інвестицій. Додатково створюють- } \\
\text { ся механізми «виходу» інвесторів } \\
\text { з фонду через механізми зворотно- } \\
\text { го викупу акцій (відкриті, інтерва- } \\
\text { льні фонди), що також забезпечує } \\
\text { мінімізацію ризиків і захисту інве-- } \\
\text { стицій. }\end{array}$ \\
\hline 15. & $\begin{array}{l}\text { Бізнесові громадські } \\
\text { організації (бізнес- } \\
\text { асоціації, організації } \\
\text { роботодавців тощо) }\end{array}$ & Інституційна невизначеність. & $\begin{array}{l}\text { Об'єднання інтересів підприємств } \\
\text { певної галузі, регіону, країни в } \\
\text { цілому для лобіювання чи захисту } \\
\text { необхідних інституційних умов } \\
\text { ведення бізнесу. }\end{array}$ \\
\hline
\end{tabular}

* Власні напрацювання автора

Поглиблений аналіз невизначеності і застосування різних форм сітьових бізнес-структур як механізму мінімізації невизначеності і спровокованих нею трансакційних витрат, відкриває широкі можливості для економічного росту окремих компаній і економіки в цілому. Адже невизначеність породжує ризики невиконання угод як в силу суб’єктивних, так і об’єктивних факторів. Трансакційні витрати відображають таку невизначеність шляхом включення премії на ризик, розмір якої залежить від вірогідності невиконання угоди, i, відповідно, виникнення додаткових витрат у одної чи обох сторін. Протягом усієї історії, стверджує Норт [14], розмір такої премії був настільки високим, що заважав розвитку складних форм обміну і таким чином обмежував можливості економічного росту. Через формування сітьових бізнес-структур проблему, що описує Норт, можна подолати.

Висновки та перспективи подальших досліджень. Виокремлення сітьових бізнес-структур як окремих альтернативних механізмів обміну наряду з ринком і фірмою, дозволяє ставити наукову задачу щодо оцінки ефективності діяльності і розвитку не окремої компанії, а групи економічних суб'єктів, які утворюють сітьові бізнес-структури або навіть галузі, як єдину систему управління і виробництва, або, іншими словами, нову конкурентну одиницю аналізу.

Ефективність і конкурентна переваги сітьової бізнес-структури в такому разі, в першому наближенні, буде відповідати критерію Калдора-Хикса [12], який був сформульований наступним чином: стан А більш вигідний за стан В, якщо ті, хто отримують вигоди від переходу до А, можуть компенсувати збитки тим, хто їх зазнав від такого переходу, і все ще залишитися у виграші. Іншими словами, інтереси окремих суб'єктів повинні трансформуватися в інтереси всієї сіті задля довгострокової адаптації та розвитку їі учасників.

Таким чином, подальші дослідження можуть стосуватися виокремлення портфелю сітьових контрактів фірми і тих конкурентних переваг, які отримує фірма, використовуючи такий сітьовий капітал. Перспективним $\epsilon$ дослідження гіпотези, що якість сітьових контрактів фірми буде відрізнятися в залежності від характеристики галузі, рівня іï динамізму, конкуренції, невизначеності, часу життєвого циклю продукції на ринку. Зокрема, стабільні галузі будуть потребувати не тільки двосторонньої взаємодії учасників сітьових бізнес-структур, але й паралельної взаємодії усіх ії членів для постійного покращення якості та зниження собівартості продукції через «криву навчання», в той час як в динамічних галузях фірми будуть намагатися побудувати портфель своїх сітьових контрактів через велику кількість двосторонніх відносин з компаніями, які не пов'язані між собою, що дозволить отримувати більше нових ідей і реалізовувати інновації, розробляти нові види продуктів та послуг. 


\section{Література}

1. Goldberg V. Regulation and Administered Contracts // Bell Journal of Economics. 1976. № 7. P. 426 -452. doi: $10.2307 / 3003265$

2. Joskow P.L. 1985. Long Term Vertical Relationships and the Study of Industrial Organization and Government Regulation // Journal of Institutional and Theoretical Economics. 1985. №141. P. 568-593.

3. Klein B., Crawford R.G. and Alchian A.A. Vertical Integration, Appropriable Rents, and the Competitive Contracting Process //Journal of Law and Economics. 1985. №28. P. 297-326. doi: 10.1086/466922

4. Kronman A.T. Contract Law and the State of Nature // Journal of Law, Economics, and Organization. 1985. №1. P.5-32.

5. Macaulay S. Non-Contractual Relations in Business: A Preliminary Study // American Sociological Review. 1963. P. 55-67. doi: 10.2307/2090458

6. Macneil I.R. The Many Futures of Contracts // Southern California Law Review. 1974. №47. P. 691-816

7. Macneil I.R. Contracts: Adjustment of Long-Term Economic Relations under Classical, Neoclassical, and Relational Contract Law // Northwestern University Law Review. 1978. №72. P. 854-905.

8. Macneil I.R. The New Social Contract: An Inquiry into Modern Contractual Relations // New Heaven and London: Yale University Press. 1980. doi: 10.2307/1288310

9. Macneil I.R. Values in Contract: Internal and External // Northwestern University Law Review. 1983. №79. P. 340-418.

10. Williamson, O.E. Markets and hierarchies: analysis and antitrust implications. New York: Free Press. 1975

11. Williamson O.E. The economic institutions of capitalism. New York: Free Press. 1985

12. Zebre R.O. Economic Efficiency in Low and Economics. Elgar. 2001. doi: 10.4337/9781843761488

13. Грив Г., Роули Т., Шапилов А. Преимущество сетей: Как извлечь максимальную пользу из альянсов и партнерских отношений / пер. с англ. М.: Альпина Паблишер, 2018. 259 с.

14. Норт Д. К. Институты, институциональные изменения и функционирование экономики. М.: Фонд экономической книги «Начала», 1997. 180 с.

Стаття надійшла 16.09.2020

Стаття прийнята до друку 30.09.2020

Доступно в мережі Internet 29.12.2020

\section{Бегунов-Новиков Л.Ю.} аспирант

кафедра бизнес-экономики и предпринимательства

Киевский национальный экономический университет Им.Вадима Гетьмана

проспект Победы, 54, г. Київ, Украина, 03057

E-mail: begunov.leonid@gmail.com

ORCID ID: 0000-0002-8020-4710

\section{КОНТРАКТНЫЕ ФОРМЫ УПРАВЛЕНИЯ СЕТЕВЫМИ БИЗНЕС-СТРУКТУРАМИ}

Парадигма неоклассической экономики базируется преимущественно на исследовании производства и потребления. Однако, большой научный интерес также вызывает организация обмена, исследования которого невозможно без анализа контрактных соглашений передачи прав собственности на активы. В статье рассмотрены формы контрактного управления сетевыми бизнесструктурами, которые используются участниками обмена в условиях неопределенности как альтернативный механизм адаптации к внешней среде через рынок (классическую контрактации) и объединенное управление (вертикальную и горизонтальную интеграцию). Впервые определены виды формальных реляционных сетевых контрактов и механизмы минимизации неопределенности, которыми они регламентируют обмен между участниками сетевых бизнес-структур. Углубленный анализ неопределенности и применения различных фрорм сетевых бизнес-структур как механизма минимизации неопределенности и спровоцированных ею трансакционных издержек, открывает широкие возможности для экономического роста отдельных компаний и экономики в целом. Ведь неопределенность порождает риски невыполнения соглашений как в силу субъективных, так и объективных факторов. Трансакционные издержки отражают такую неопределенность путем включения премии на риск, размер которой зависит от вероятности невыполнения соглашения, и, соответственно, возникновения дополнительных расходов в одной или обеих сторон. 
Описаны основные условия неопределенности, которые позволяют управленцам, субъектам принятия решений делать выводы о целесообразности фрормирования сетевых бизнес-структур как наиболее эффрективных и наименее трансакционных расходных структур управления в условиях неопределенности.

Выделение сетевых бизнес-структур как отдельных альтернативных механизмов обмена наряду с рынком и фрирмой, ставит научную задачу по оценке эффективности деятельности и развития не отдельной компании, а группы экономических субъектов, образующих сетевые бизнесструктуры или даже отрасли, как единую систему управления и производства.

Ключевые слова: Многопользовательские бизнес-структуры, стратегические альянсы, консорциумы, концерны, форварды, опционы, венчурное финансирование, ассоциации предприятий, реляционный контракт.

\section{Bigunov-Novikov L. \\ Postgraduate}

Department of Economics and Business Entrepreneurship

Kiev National Economic University named after V. Hetman

Prospect Peremogy, 54, Kyiv, Ukraine, 03057

E-mail: begunov.leonid@gmail.com

ORCID ID: 0000-0002-8020-4710

\section{THE CONTRACT FORM OF NETWORK BUSINESS STRUCTURES MANAGEMENT}

The paradigm of neoclassical economics is based mainly on the investigations of production and consumption. However, the organization of exchange is also of great scientific interest, the study of which is impossible without the analysis of contractual agreements on the transfer of ownership of assets. The article considers the forms of contractual management of network business structures, which are used by exchange participants in conditions of uncertainty as an alternative mechanism of adaptation to the external environment through the market (classical contracting) and integrated management (vertical and horizontal integration). For the first time, the types of formal relational network contracts and mechanisms for minimizing uncertainty, which regulate the exchange between participants in network business structures, have been identified. An in-depth analysis of uncertainty and the use of various forms of network business structures as a mechanism to minimize uncertainty and the transaction costs provoked by it, opens wide opportunities for economic growth of individual companies and the economy as a whole. After all, uncertainty creates risks of non-fulfillment of agreements due to both subjective and objective factors. Transaction costs reflect such uncertainty by including a risk premium, the amount of which depends on the probability of default, and, accordingly, the occurrence of additional costs for one or both parties.

The main conditions of uncertainty have been described, which allow managers, decision-makers to draw conclusions about the feasibility of forming network business structures as the most effective and least transactionally costly management structures in conditions of uncertainty.

The separation of network business structures as separate alternative mechanisms of exchange along with the market and the firm, poses a scientific task to assess the effectiveness and development of not a single company but a group of economic entities that form network business structures or even industries as a single management system and production.

Key words: Network business structures, strategic alliances, consortiums, concerns, forwards, options, venture financing, business associations, relational contract.

\section{References}

1. Goldberg, V. (1976). Regulation and Administered Contracts. Bell Journal of Economics, (7), 426 -452. doi: $10.2307 / 3003265$

2. Joskow, P. L. (1985). Long Term Vertical Relationships and the Study of Industrial Organization and Government Regulation. Journal of Institutional and Theoretical Economics, (141), 568-593.

3. Klein, B., Crawford, R. G., \& Alchian, A. A. (1985). Vertical Integration, Appropriable Rents, and the Competitive Contracting Process. Journal of Law and Economics, (28), 297-326. doi: 10.1086/466922

4. Kronman, A. T. (1985). Contract Law and the State of Nature. Journal of Law, Economics, and Organization, (1), 5-32.

5. Macaulay, S. (1963). Non-Contractual Relations in Business: A Preliminary Study. American Sociological Review, 55-67. doi: 10.2307/2090458 
6. Macneil, I. R. (1974). The Many Futures of Contracts. Southern California Law Review, (47), 691-816.

7. Macneil, I. R. (1978). Contracts: Adjustment of Long-Term Economic Relations under Classical, Neoclassical, and Relational Contract Law. Northwestern University Law Review, (72), 854-905.

8. Macneil, I. R. (1980). The New Social Contract: An Inquiry into Modern Contractual Relations. New Heaven and London: Yale University Press. doi: 10.2307/1288310

9. Macneil, I. R. (1983). Values in Contract: Internal and External. Northwestern University Law Review, (79), 340-418. Press.

10. Williamson, O. E. (1975). Markets and hierarchies: analysis and antitrust implications. New York: Free

11. Williamson, O. E. (1985). The economic institutions of capitalism. New York: Free Press.

12. Zebre, R. O. (2001). Economic Efficiency in Low and Economics. Elgar. doi: 10.4337/9781843761488

13. Griv, G., Rouli, T., \& Shapilov, A. (2018). Preimuschestvo setey: Kak izvlech maksimalnuyu polzu iz alyansov i partnerskih otnosheniy. Moscow: Alpina Pablisher.

14. Nort, D. K. (1997). Institutyi, institutsionalnyie izmeneniya i funktsionirovanie ekonomiki. Moscow: Fond ekonomicheskoy knigi «Nachala».

Received 16 September 2020

Approved 30 September 2020

Available in Internet 29.12.2020

Цитування згідно ДСТУ 8302:2015

Бігунов-Новіков Л.Ю. Контрактні форми управління сітьовими бізнес-структурами // Економіка харчової промисловості. 2020. Т.12, вип. 4. С. 17-25. doi: 10.15673/fie.v12i4.1907

Cite as APA style citation

Bigunov-Novikov, L. (2020). The contract form of network business structures management. Food Industry Economics, 12(4), 17-25. doi: 10.15673/fie.v12i4.1907 